\title{
JUSTIÇA E PODER DISCRICIONÁRIO
}

\author{
THADEU WEBER ${ }^{*}$
}

\begin{abstract}
RESUMO: O artigo discute o tema do poder discricionário dos juízes a partir do desenvolvimento da concepção de justiça e de seus princípios na perspectiva de J. Rawls e C. Perelman. Vale-se da distinção entre regras e princípios de R. Dworkin para defender a tese segundo a qual não há discricionariedade no âmbito do poder judicial. Na ausência de regras claras disponíveis para a solução dos casos difíceis o recurso dos juízes deve ser aos princípios vigentes (escritos ou não) na comunidade ético-política. Esse é seu poder de interpretação.

PALAVRAS-CHAVE: Justiça, Poder Discricionário, Regras, Princípios, Interpretação, Moral, Direito.
\end{abstract}

ABSTRACT: This paper discusses the subject concerning the judicial discretion starting from the development of justice's conception and its principles in the view of J. Rawls and C. Perelman. The article makes use of the distinction between rules and principles of R. Dworkin, in order to defend the thesis according to what there isn't discretion in the field of judicial power. When there are lacking clear rules at disposal for the solution of hard cases the judges must resort to the principles in force (written or not) in the ethicalpolitical community. This is their power of interpretation.

KEYWORDS: Justice, Judicial Discretion, Principles, Rules, Interpretation, Moral, Law.

SUMÁRIO: 1. O que é justiça? 1.1. Rawls e a "justiça como eqüidade”. 1.1.1. A "posição original” e o problema da fundamentação dos princípios de justiça. 1.1.2. Os princípios de justiça: formulações e reformulações. 1.2. Perelman: Justiça, argumentação e o "auditório universal”. 2. Regras e princípios. 3. O Poder Discricionário (Dworkin e Perelman) 4. O poder discricionário dos juízes e o “auditório universal”. 5. Referências Bibliográficas.

\section{O QUE É JUSTIÇA?}

A justiça tem sido objeto de estudo, discussão e, sobretudo, anseio de todo cidadão e de todas as corporações em todos os tempos. É um dos valores universais mais reconhecidos. Queremos que as leis injustas sejam abolidas e que as instituições em geral primem pela justiça. Do judiciário, esperamos decisões justas em todos os níveis. "Se a justiça perecer, não valerá mais a pena os homens viverem sobre a terra”, escreve Kant na Metafísica dos Costumes.

Perelmann, em seu livro "Ética e Direito", diz que numa sociedade ideal não seriam necessários nem juízes nem advogados, pois as leis estariam inscritas no coração, na consciência e na razão de todos os homens (cf. p. 373). O fato é que temos muitos juízes e muitos advogados. Vivemos numa sociedade real, eivada de

\footnotetext{
* Doutor em Filosofia. Professor Titular da Pontifícia Universidade Católica do Rio Grande do Sul-PUCRS
} 
contradições e injustiças. Leis, e cada vez mais leis, são o objeto de acordos e apontadas como tentativas de viabilizar a convivência harmônica dos cidadãos. Acerta Perelmann ao afirmar, na mesma obra, que "a diversidade das leis é prova de nossa ignorância da verdadeira justiça” (p. 374). Poucas coisas podem ser deixadas para o bom senso e ao senso de justiça das pessoas. Pactos sem previsão de penalidades não são levados a sério. Ou como escreve Hobbes: "Pactos sem espada não passam de palavras, sem força para dar qualquer segurança a ninguém” (Leviatã, p. 103).

Mas o que é justiça? Que princípios a constituem? Como formalizá-los e fundamentá-los? Em que medida orientam ou deveriam orientar as decisões do judiciário? As perguntas se repetem, mas as respostas estão longe de um consenso. A discussão sobre o poder discricionário dos juízes passa necessariamente pelo conceito de justiça e seus princípios. O tema é antigo e os autores que dele tratam são muitos. Rawls, Perelmann e Dworkin estão entre os mais significativos.

\subsection{Rawls e a "justiça como eqüidade"}

A “justiça como equidade” de J. Rawls é certamente uma das mais importantes concepções de justiça surgidas no século XX, sobretudo no que se refere à construção e formulação de seus princípios e a sua limitação ao "domínio do político”. Mas como a maioria dos grandes pensadores, também ele efetuou revisões e reformulações. Elas envolvem mudanças na formulação e conteúdo dos princípios da justiça, na fundamentação desses princípios a partir da "posição original” e na explicitação de como a teoria da justiça deve ser entendida, isto é, como uma concepção política de justiça (cf. J.E.R. p. XVII) ${ }^{1}$.

$\mathrm{Na}$ tentativa de explicitar alguns aspectos da "justiça como eqüidade”, incorporando as revisões do próprio Rawls, podemos partir de um pressuposto básico: as pessoas são invioláveis nos seus direitos e liberdades básicos. Se nos colocarmos diante da alternativa: direitos e liberdades fundamentais por um lado, e as vantagens econômicas e sociais, por outro, a prioridade sempre recairá sobre a primeira opção. Os direitos e liberdades fundamentais não estão sujeitos a qualquer negociação ou vantagem econômica ou política. Isso já define uma linha de argumentação que caracteriza o Estado Democrático de Direito. Significa que as liberdades fundamentais da pessoa não podem ser sacrificadas em nome de interesses econômicos e sociais. É o liberalismo político.

Surgem, no entanto, importantes questionamentos: como chegar a um consenso sobre uma concepção de justiça que deveria orientar nossas instituições em meio à diversidade de convicções morais, filosóficas e religiosas? Como compatibilizar uma concepção de justiça com o pluralismo razoável? Ou, quais são os princípios de justiça mais adequados para orientar e realizar a liberdade e a igualdade? Essas questões levaram Rawls a explicitar sua concepção de “justiça como eqüidade” e definí-la como uma concepção política e pública de justiça. A idéia de sociedade bem-ordenada

1 Siglas usadas no presente texto: L.P. Liberalismo Político; J.E.R. Justiça como eqüidade: uma reformulação; T.J. Uma Teoria da Justiça (Rawls); E.D. Ética e Direito (Perelman); L.D.S. Levando os Direitos a Sério (Dworkin). 
(regulada por aquela concepção de justiça), tal como apresentada em Teoria, é pouco realista, reconhece o autor. Dá a entender que se trata de uma "teoria moral abrangente", teoria que inclui todos os aspectos da vida humana. Ora, nesse contexto não é possível um consenso. É necessária, então, uma limitação no sentido de que somente os aspectos políticos podem ser considerados. Fala-se, por isso, no Liberalismo Político, de concepção política de justiça. Esta pode conquistar o apoio das doutrinas abrangentes, mas uma doutrina abrangente nunca será objeto de um consenso.

1.1.1. A “posição original” e o problema da fundamentação dos princípios de justiça

Como elaborar ou construir princípios de justiça para uma sociedade justa e estável? É possível atingir um consenso? Ou, no questionamento de Rawls, “como é possível existir, ao longo do tempo, uma sociedade justa e estável de cidadãos livres e iguais que se mantém profundamente divididos por doutrinas religiosas, filosóficas e morais razoáveis?” (L.P. p. 91). Trata-se de uma questão central: em meio ao pluralismo de idéias, o autor investiga a possibilidade de uma sociedade justa, orientada por uma concepção política de justiça. A formulação dessa concepção, no entanto, passa por várias revisões e evoluções. O problema colocado em Teoria é reformulado e explicitado enquanto concepção de justiça que diz respeito apenas aos aspectos políticos, ou seja, a concepção de justiça adotada limita-se ao "domínio do político”. Essa delimitação ou restrição é decisiva para a análise do poder de interpretação e decisão de quem exerce o poder judiciário. Existem padrões claros para a tomada de decisões.

\subsubsection{Pressupostos}

A resposta às questões formuladas inclui alguns pressupostos. $\mathrm{O}$ primeiro deles é o conceito de “pessoa”.

As pessoas são, obviamente, as grandes beneficiadas com a implantação de um "sistema de cooperação social”. Como esse sistema não é dado, mas requer a participação ativa das pessoas, atribui-se-lhes, na perspectiva de Rawls, "duas faculdades morais" ou "capacidades da personalidade moral”, que são capacidades para a efetiva participação na cooperação social e à construção dos princípios de justiça que devem orientar as instituições sociais. São elas: a capacidade de ter um "senso de justiça" (a capacidade de ser razoável) e a capacidade de ter uma “concepção do bem” (de ser racional). "Senso de justiça é a capacidade de entender a concepção pública de justiça que caracteriza os termos eqüitativos da cooperação social, de aplicá-la e de agir de acordo com ela”. (...) “A capacidade de ter uma concepção do bem é a capacidade de formar, revisar e procurar concretizar racionalmente uma concepção de vantagem racional pessoal, ou bem” (L.P. p. 62 e p. 356). Portanto, estamos pressupondo certas capacidades por parte dos cidadãos como condição de possibilidade para a construção e compreensão da concepção política de justiça. ${ }^{2}$ Quem não pode exercer essas capacidades morais não pode participar da sociedade como membro normal e cooperativo. É oportuno salientar que, em Teoria, ao tratar das partes na posição

\footnotetext{
${ }^{2}$ O conceito de pessoa, como “capacidade jurídica”, é também central como ponto de partida de Hegel na Filosofia do Direito. “Sê pessoa e respeite os outros como pessoas” é o preceito do Direito (§ 36).
} 
original na condição de seres iguais, o autor americano refere-se aos "seres humanos" como "pessoas éticas". As caracteriza como criaturas que têm senso de justiça e uma concepção do bem. No Liberalismo Político, tendo em vista a explicitação de sua "justiça como eqüidade" como uma concepção política de justiça, fala de uma “concepção política de pessoa” à qual é preciso recorrer para estabelecer a posição original. Por outra, o adequado desenvolvimento das duas faculdades da personalidade moral (senso de justiça e concepção do bem) requer a garantia e a proteção dos direitos e liberdades fundamentais. E o efetivo exercício destes requer o estabelecimento de prioridades e ajustes. É importante destacar que o fato de possuírem as capacidades morais "no grau mínimo necessário", e terem as capacidades normais para ser um membro cooperativo da sociedade, são características fundamentais das pessoas (cf. L.P. p. 124). As capacidades morais são "condições necessárias e suficientes" para alguém ser considerado "membro pleno e igual da sociedade em questões de justiça social” (L.P. p. 356). Sem isso não é possível a cooperação social. Perelman as enquadraria no conjunto das pessoas que constituem o "auditório universal”, isto é, pessoas razoáveis e competentes. As características citadas por Rawls são, portanto, condições necessárias para que as pessoas possam ser membros de uma sociedade cooperativa. "Alguém que não desenvolveu e não pode exercer as capacidades morais no grau mínimo exigido não pode ser membro normal e plenamente cooperativo da sociedade ao longo de toda a vida” (L.P. p. 119). Portanto e em síntese, Rawls está supondo como elementos básicos das concepções dos cidadãos: as capacidades morais já citadas; as "faculdades intelectuais de julgamento, pensamento e inferência"; uma determinada "concepção do bem”; “as capacidades e qualificações necessárias para serem membros normais e cooperativos da sociedade durante toda a vida” (L.P. p. 126).

Outro pressuposto da Teoria da Justiça de J. Rawls é a idéia de "sociedade bem-ordenada”, uma sociedade regulada por uma “concepção política de justiça” e não, como dava entender em Teoria, por uma concepção de justiça como uma doutrina filosófica abrangente ou uma concepção moral abrangente. A idéia de uma sociedade bem-ordenada significa, basicamente, três coisas: 1 . Trata-se de uma sociedade na qual todos conhecem e aceitam os mesmos princípios de justiça; 2 . Todos reconhecem que a estrutura básica, isto é, as principais instituições políticas e sociais respeitam e estão em concordância com aqueles princípios; 3. Os cidadãos têm um senso de justiça que, via de regra, os faz agir de acordo com as instituições mais importantes da sociedade (cf. L.P. p. 79 e T.J. p. 504). A ênfase está no fato de que numa sociedade bem-ordenada haja uma concepção de justiça publicamente reconhecida, isto é, todos aceitam os mesmos princípios de justiça ${ }^{3}$. Essa é uma condição necessária para que se possa ter maior estabilidade na sociedade. Quando as instituições são justas, os indivíduos que delas participam desenvolverão gradualmente um senso de

\footnotetext{
${ }^{3}$ O próprio Rawls considera a idéia de "sociedade bem-ordenada”, conforme apresentada em Teoria, pouco realista ou um "conceito extremamente idealizado" (cf. L.P. p. 78). Por isso, a revisão no Liberalismo Político: a teoria da justiça deveria estar voltada para os objetivos políticos e a idéia da sociedade bem-ordenada deve ser entendida nesse contexto. Dizer que nessa sociedade todos reconhecem os mesmos princípios de justiça significa dizer que reconhecem a mesma concepção política de justiça. Fora disso não há possibilidade de consenso.
} 
justiça que, por sua vez, fortalecerá as instituições. Daí a auto-sustentabilidade da "justiça como eqüidade".

Impõe-se, ainda, um terceiro pressuposto: O Estado Democrático de Direito. Trata-se de uma declaração de direitos, já expressos pelos princípios da justiça, sobretudo, o primeiro, como veremos. "A concepção formal da justiça, a administração regular e imparcial das normas comuns, transforma-se no Estado de Direito quando se aplica ao sistema jurídico", afirma o autor (T.J. p. 257). O Estado de Direito caracteriza-se pelo ordenamento constitucional, pela participação dos cidadãos nas decisões políticas e pelas eleições livres. Rawls está falando de uma sociedade bem-ordenada, isto é, de uma sociedade quase justa e que requer um regime democrático. A discussão sobre a obediência a leis injustas, a desobediência civil e a objeção de consciência, por exemplo, pressupõe a existência de um Estado Democrático de Direito. Neste os cidadãos reconhecem a legitimidade da Constituição. Aliás, toda a Teoria da justiça de J. Rawls desenvolve-se a partir dessa concepção de Estado. Outras formas de governo simplesmente não são objeto de análise para fins de aplicação de algum tipo de resistência.

\subsubsection{A "posição original” e o "véu da ignorância"}

$\mathrm{O}$ que se quer com uma teoria da justiça? A descrição da justiça como um dever-ser? Como estabelecê-la? Requer-se o estabelecimento de princípios (de justiça) orientadores para as instituições sociais? Como formulá-los? Qual é o ponto de partida?

Todos os cidadãos querem uma sociedade organizada como um "sistema eqüitativo de cooperação entre pessoas livres e iguais" (J.E.R. p. 20). Como fazê-lo? Como "determinar os termos eqüitativos de cooperação" (idem p. 20 e L.P., p. 65). São ditados pela lei divina? São resultados de uma intuição racional? Ou são estabelecidos por meio de um acordo entre os cidadãos? (cf. L.P. p. 65). Para a "justiça como eqüidade" "os termos eqüitativos de cooperação social provêm de um acordo celebrado por aqueles comprometidos com ela" (J.E.R. p. 20; ver tb. L.P. p. 66). Uma concepção de justiça, portanto, precisa ser construída pelos cidadãos interessados na cooperação. Rawls defende a tese segundo a qual os princípios de justiça política são o resultado de um procedimento de construção. Mas qual a metodologia mais adequada? Qual o procedimento correto e como encontrá-lo? Será pela reflexão, mediante o uso de nossa capacidade de raciocínio? Será o desenvolvimento de um processo argumentativo de acordo com o "auditório universal”? ${ }^{4}$.

No intuito de estabelecer uma situação de eqüidade para a escolha dos princípios de justiça, Rawls propõe o que chama de "posição original”. Nessa escolha é preciso excluir certos fatos (irrelevantes do ponto de vista jurídico), certas situações particulares e interesses subjetivos, certas informações, para que se crie uma situação hipotética de igualdade, na qual não haja favorecimento de ninguém. As partes, sentencia o autor, devem situar-se por trás de um "véu de ignorância" $\mathrm{O}$ acordo deve

\footnotetext{
${ }^{4}$ Sobre esse assunto, ver o livro de C. Perelman, Ética e Direito. Primeira parte. O tema também será desenvolvido mais adiante.

${ }^{5} \mathrm{O}$ tema do "véu da ignorância” como aspecto constitutivo da "posição original” é amplamente desenvolvido em Teoria, p. 146; O Liberalismo Político, p. 66; e Justiça como Eqüidade: uma reformulação, p. 21.
} 
situar as pessoas livres e iguais de "modo eqüitativo" e "não pode permitir que alguns tenham posições de negociação mais vantajosas do que as de outros”. Ameaças de força e coação devem estar excluídas (J.E.R. p. 21). A posição original deve abstrair as contingências do mundo social; deve "eliminar as vantagens de barganha" que são inevitáveis nas instituições básicas da sociedade (L.P. p. 66). Sem isso não é possível um consenso sobre os princípios da justiça. A "construção" de uma concepção política de justiça requer que as partes se situem numa posição de eqüidade. Supõe-se que as partes "não conhecem seu lugar na sociedade, sua posição de classe ou status social, sua boa ou má sorte na distribuição das capacidades e talentos naturais, tudo isso dentro de um leque normal de variação” (L.P. p. 325).

É importante salientar que o acordo referido não é historicamente situado ou situável, mas, ao contrário, ele é hipotético e ahistórico. "É hipotético na medida em que nos perguntamos o que as partes (...) poderiam acordar, ou acordariam, e não o que acordaram. (...) É ahistórico na medida em que não supomos que o acordo tenha sido concertado alguma vez ou venha a ser celebrado” (J.E.R. p. 23). Essa explicitação é esclarecedora a partir das críticas feitas à Teoria. Aproxima-se, como se pode observar, da concepção de natureza humana de Rousseau. ${ }^{6}$

Mas se o acordo é hipotético e de acordos hipotéticos não se seguem obrigações, qual é, então, o sentido desse acordo? Para Rawls, a importância do acordo está no fato de ser "um procedimento de representação ou um experimento mental para os propósitos de esclarecimento público" (J.E.R. p. 24). A posição original é uma espécie de modelo que, por um lado, situa as partes dentro de condições eqüitativas, nas quais o acordo de cooperação deve realizar-se e, por outro, é um modelo que implica restrições dentro das quais as partes podem propor certos princípios de justiça. Em Teoria, o autor americano refere-se explicitamente às "restrições formais do conceito do justo” e às “circunstâncias da justiça” (T. J. p. 136). Quanto as primeiras salienta que os princípios de justiça devem ser gerais em sua formulação e universais em sua aplicação. “Que todos devem seguir meus interesses” é, certamente, um exemplo que satisfaz a universalidade (aplica-se a todos), mas não a generalidade. Além disso, os princípios devem atender a condição de publicidade e, em caso de conflitos, a concepção do justo deve impor uma “ordenação”, isto é, deve hierarquizar as ordenações. Ademais, os princípios têm um "caráter terminativo", ou seja, são a "última instância de apelação”, não sendo mais possível recorrer a outras instâncias além deles. Quanto às circunstâncias, é digno de nota que a cooperação dos indivíduos se dá dentro de um território geográfico definido, onde cada um deles tem seu próprio plano de vida. É importante chamar a atenção para o fato de que o "véu da ignorância" é um elemento a mais, acrescido às circunstâncias da justiça e às restrições formais ao conceito do justo. Todos esses aspectos são limites que tornam possível a formulação dos princípios de justiça. O "véu da ignorância”, especificamente, é uma espécie de limite ao conhecimento, com o objetivo de viabilizar a negociação das partes. Mas, saliente-se, é um dos elementos, além das circunstâncias e restrições formais. Estas seriam insuficientes para viabilizar o intuito de uma teoria da justiça. O "véu da ignorância”,

${ }^{6}$ Ver Discurso sobre a origem e os fundamentos da desigualdade entre os homens, prefácio e introdução. 
portanto, soma-se às outras condições da posição original, eliminando diferenças quanto à "situações privilegiadas de negociação" (J.E.R. p. 122). O princípio de eqüidade é respeitado na medida em que as partes estiverem situadas de forma simétrica.

O importante é que as partes, na posição original, devem estar "simetricamente situadas”. Isso indica que nos aspectos mais importantes, em questões de justiça política, os cidadãos são iguais. Privilégios e vantagens na negociação devem ser momentaneamente eliminados. Esse é o sentido do "véu da ignorância”. Dentro dessa perspectiva de o acordo ser hipotético e ahistórico, compreende-se, também, porque as partes (os representantes dos cidadãos) são "pessoas artificiais”, isto é, "meros habitantes do nosso procedimento de representação” (J.E.R. p. 117). A posição original é um “artifício da razão”. No Liberalismo Político, ao tratar da posição original, o autor fala em “artifício de representação” (cf. p. 68).

Embora a posição original seja hipotética e ahistórica, os princípios escolhidos pelas partes nessa posição fazem parte de uma lista de "concepções de justiça política existentes em nossa tradição de filosofia política. (...) O que fazemos é oferecer às partes uma lista de princípios, um menu, por assim dizer” (J.E.R. p. 117). Esta lista é constituída, conforme referido, pelas mais importantes concepções de justiça e dentro delas as partes precisam escolher e chegar a um acordo em torno de uma das alternativas propostas. Os princípios de justiça são, portanto, selecionados a partir de uma lista dada. A posição original, segundo o autor, é um "procedimento de seleção" (idem, p. 117). O que Rawls quer mostrar é que a "justiça como eqüidade”, entendida como uma concepção política de justiça e constituída pelos dois princípios citados, seria a alternativa escolhida, havendo em torno dela, portanto, um acordo. Poder-se-ia alegar que nem todos os princípios estão incluídos nessa lista. Podem ser acrescentados, segundo o autor americano. Isso, no entanto, não alteraria o acordo resultante em torno dos dois princípios que constituem a "justiça como equidade”.

É importante salientar que os princípios da justiça não são deduzidos das condições da posição original, mas são escolhidos pelas partes a partir de um "menu" que lhes é apresentado. É oportuno insistir: além das circunstâncias da justiça e das restrições formais ao conceito do justo, o "véu da ignorância”, característica da posição original, é um elemento a mais para possibilitar um acordo entre as pessoas. Ele elimina as diferenças no que se refere a certos privilégios de negociação. Enfim, coloca as partes numa situação de eqüidade. Esse acordo exige que sejam criadas condições eqüitativas e requer certas restrições para a construção dos princípios de justiça. A propósito, saliente-se que a posição original, enquanto "artifício procedimental de representação”, não é construído. O que é construído é o "conteúdo de uma concepção política de justiça” que, no caso da "justiça como eqüidade”, são os dois princípios da justiça (cf. L.P. p. 148). O resultado da posição original é a produção dos princípios de justiça apropriados para cidadãos livres e iguais (cf. L.P. p. 117). É a “justiça procedimental pura”. Quaisquer que sejam os princípios acordados pelas partes, serão tidos como justos. O justo é o resultado de um procedimento. ${ }^{7}$

${ }^{7}$ Sobre a diferença entre justiça procedimental pura e justiça procedimental perfeita, ver O Liberalismo Político, p. 117 e, mais detalhadamente, Uma Teoria da Justiça, p. 89. 
O resultado da posição original é a produção dos princípios de justiça adequados aos cidadãos livres e iguais. Na justiça procedimental pura não há a determinação prévia de nenhum critério de justiça. Não há um critério independente (definido em separado) para decidir um resultado justo, como é o caso da justiça procedimental perfeita, mas há um procedimento que, se corretamente aplicado, conduzirá a um resultado justo. As partes, na posição original, são livres para acordar os princípios que considerarem apropriados para todos. Enfim, os princípios são justos porque objeto de um acordo na posição original. É isso que legitima o recurso dos juízes a eles, principalmente nos casos difíceis (hard cases).

Além disso, ao tratar da "razão pública", Rawls chama a atenção para o fato de que a eficácia do acordo dos princípios de justiça e a sustentação de uma "base pública de justificação" requerem também um acordo sobre "as diretrizes da discussão pública e sobre que critérios decidem que informações e conhecimentos são relevantes na discussão das questões políticas" (J.E.R. p. 126). O acordo original, portanto, constitui-se de um acordo sobre os princípios de justiça e de um acordo sobre "os princípios de argumentação e as regras de verificação à luz das quais os cidadãos devem decidir se os princípios de justiça se aplicam, quando e até que ponto eles são satisfeitos” (J.E.R. p. 126). É o que torna a razão pública. Por isso, além de referir-se aos valores de justiça política (os referentes aos princípios de justiça, como os da liberdade política igual), refere-se, também, aos valores da razão pública (os referentes "às diretrizes de discussão pública" e das etapas que garantem que o debate seja livre e público). Nesse segundo tipo entram também as virtudes da razoabilidade e da boa fé.

Toda essa discussão sobre a construção dos princípios de justiça tem como preocupação central encontrar uma forma de chegar a um acordo em torno do que deveria orientar e organizar um Estado Democrático de Direito. Os parâmetros e os limites do judiciário também estão aí circunscritos. É fácil observar que a fundamentação desses princípios é o grande desafio.

\subsubsection{Os princípios de justiça: formulações e reformulações}

Partimos da idéia da sociedade como um "sistema eqüitativo de cooperação entre pessoas livres e iguais” (J.E.R. p. 20). Isso posto, quais são os princípios de justiça mais adequados para determinar direitos e deveres, para regular as desigualdades sociais e econômicas dos cidadãos?

De acordo com a "justiça como eqüidade” os princípios da justiça são resultado de um acordo numa situação inicial de eqüidade. Eles são escolhidos para constituírem uma concepção de justiça que deve regular as instituições e suas reformas. Definida a concepção de justiça, cabe às partes "escolher uma Constituição e uma legislatura para elaborar leis” (T.J. p. 14). A Constituição e as leis, portanto, devem ser elaboradas em consonância com os princípios da justiça. Como formulá-los e fundamentá-los?

\subsubsection{A formulação dos princípios}

Os dois princípios de justiça que as partes, submetidas ao "véu da ignorância" (tomado como "artifício de representação"), escolherão e em torno dos quais haverá um consenso, são os seguintes: “a) cada pessoa tem o mesmo direito irrevogável a 
um esquema plenamente adequado de liberdades básicas iguais que seja compatível com o mesmo esquema de liberdades para todos; e b) as desigualdades sociais e econômicas devem satisfazer duas condições: primeiro, devem estar vinculadas a cargos e posições acessíveis a todos em condições de igualdade eqüitativa de oportunidades; e, em segundo lugar, têm de beneficiar ao máximo os membros menos favorecidos da sociedade (o princípio da diferença)” (J.E.R. p. 60).

Levando em conta as características da posição original, podemos afirmar que esses princípios são justos porque resultam de um “consenso sobreposto”, mesmo que este nunca seja plenamente atingido. São justos porque são objeto de um acordo na posição original.

Essa é a formulação dos princípios encontrada em Justiça como eqüidade: uma reformulação, um dos últimos textos do autor e que apresenta revisões e explicitações significativas dos princípios discutidos em Teoria.

A primeira explicitação refere-se ao fato dessas formulações expressarem melhor a concepção política de justiça, objetivo fundamental de Rawls. Trata-se de uma formulação mais clara de como a "justiça como eqüidade" deve ser entendida. Diz respeito a uma concepção mais restritiva do que a de Teoria, que dá ênfase a uma doutrina moral abrangente. Que a concepção de justiça se limite ao domínio do político é condição de possibilidade dela "conquistar o apoio de um consenso sobreposto que abarque as doutrinas religiosas, filosóficas e morais razoáveis” (L.P. p. 52). Além disso, é digno de nota que o primeiro princípio, além da estrutura básica da sociedade, aplica-se mais precisamente à Constituição, escrita ou não. Isto significa dizer que os direitos e liberdades básicos devem ser garantidos pela Constituição. Eles são os elementos constitucionais essenciais.

Se no início de Teoria o autor fala em "direito igual ao mais abrangente sistema de liberdades básicas iguais”, na segunda parte de Teoria, no Liberalismo Político e em Justiça como eqüidade: uma reformulação, prevendo possíveis conflitos entre os direitos e liberdades fundamentais, no seu efetivo exercício, refere-se ao "sistema total de liberdades básicas” ou em "esquema plenamente adequado de liberdades básicas”, conforme formulação citada. Isso mostra que as liberdades não são absolutas e que limites, no seu exercício, são admissíveis e, por vezes, necessários.

Ainda no que se refere ao primeiro princípio e no intuito de explicitá-lo melhor, o autor em pauta apresenta uma lista de liberdades básicas. Essa lista é especificada já em Teoria e revista no Liberalismo Político e em Justiça como eqüidade: uma reformulação. Nesta obra a lista apresentada é a seguinte: "liberdade de pensamento e de consciência; liberdades políticas (por exemplo, o direito de votar e de participar da política) e liberdade de associação, bem como os direitos e liberdades especificadas pela liberdade e integridade (física e psicológica) da pessoa; e, finalmente, os direitos e as liberdades abarcados pelo estado de direito" (J. E. R. p. 62).

Uma questão central precisa ser colocada: A partir de que fonte esses direitos e liberdades são indicadas? Como pode essa lista ser formulada? São intuições das partes na posição original? Por que essas liberdades e não outras? É essa lista exaustiva? 
A resposta é encontrada no Liberalismo Político (p. 345) e principalmente em Justiça como Eqüidade: uma reformulação (p. 63). Há, aqui, um significativo avanço em relação às idéias desenvolvidas em Teoria. A formulação da lista das liberdades básicas, segundo o autor, pode ser feita de duas maneiras: uma é histórica e outra é analítica. Do ponto de vista histórico, basta examinar os regimes democráticos mais bem sucedidos e teremos uma lista de direitos e liberdades básicos mais protegidos. Do ponto de vista analítico basta avaliar "quais são as liberdades que fornecem as condições políticas e sociais essenciais para o adequado desenvolvimento e pleno exercício das duas faculdades morais das pessoas livres e iguais” (J.E.R. p. 64). As duas faculdades referem-se à capacidade de ter um senso de justiça e à capacidade de ter uma concepção do bem. O desenvolvimento dessas duas faculdades nos levará à formulação de uma lista de direitos e liberdades básicos como condições de sua possibilidade. Não é possível desenvolver o senso de justiça sem que as liberdades políticas e de pensamento estejam asseguradas. Além do mais, não se pode desenvolver uma concepção do bem sem liberdade de consciência. Portanto, a lista de direitos e liberdades básicos apresentada indica as condições fundamentais para o pleno exercício das duas faculdades morais das pessoas livres e iguais.

Além da lista, o autor americano vê a necessidade de uma melhor especificação dessas liberdades básicas, tema também desenvolvido em Teoria. A título de exemplo, refere o direito de propriedade e a liberdade de expressão. A propósito do direito de adquirir e fazer uso exclusivo da propriedade pessoal esclarece que o intuito fundamental desse direito "é proporcionar uma base material suficiente para a independência da pessoa e um sentimento de auto-respeito, ambos essenciais para o desenvolvimento e exercício adequados das faculdades morais” (J.E.R. p. 160 e L.P. p. 352). Mas como liberdade fundamental, concepções mais abrangentes desse direito devem ser evitadas: o direito de propriedade não inclui o direito de herança, o direito de possuir meios de produção e recursos naturais (cf. L.P. p. 352). Essas concepções mais amplas não são condições necessárias para o desenvolvimento e pleno exercício das faculdades morais. Podem, no entanto, ser objeto de avaliação nos estágios posteriores (o legislativo, por exemplo), quando se tem mais informações sobre as circunstâncias e tradições de uma sociedade, mas não no da adoção dos princípios da justiça (primeiro estágio), quando as partes estão submetidas ao "véu da ignorância". 8

No que se refere ao segundo princípio, Rawls chama a atenção para o "significado da igualdade eqüitativa de oportunidades”(J.E.R. p. 61). Essa igualdade "exige não só que cargos públicos e posições sociais estejam abertos no sentido formal, mas que todos tenham uma chance eqüitativa de ter acesso a eles” (idem, p. 61). Essa chance não pode depender da classe social das pessoas, mas tão somente de seus talentos e habilidades e da disposição para exercê-los. Além do mais, o segundo princípio se aplica, também, à distribuição de renda e riqueza, que não precisa ser igual, mas deve trazer vantagens para todos.

\footnotetext{
${ }^{8}$ Sobre “O direito de propriedade em Rawls e a Constituição Federal de 1988”, ver meu artigo na Revista Direito e Justiça, Porto Alegre, V.32, N 2, 2006, pp. 207-219.
} 
Ainda quanto ao segundo princípio, uma pergunta se impõe e requer esclarecimentos: quem são os menos favorecidos?

Trata-se de uma questão que recebe especial atenção em Justiça como eqüidade: uma reformulação. O autor retoma a idéia de "bens primários", já apresentados e explicitados em Teoria. Descreve-os como sendo condições necessárias para que "os cidadãos possam desenvolver-se adequadamente e exercer plenamente suas duas faculdades morais” que, como visto, são o senso de justiça e a concepção do bem (J.E.R. p. 81). São as "coisas necessárias e exigidas" para que os cidadãos possam desenvolver-se como "membros plenamente cooperativos da sociedade". São bens que não só é desejável ou racional que as pessoas tenham, mas são coisas que os cidadãos precisam como pessoas livres e iguais, para uma vida digna. O autor indica uma série desses bens: os direitos e liberdades básicos (as liberdades de consciência e pensamento, etc. ); as liberdades de movimento e de livre escolha de ocupação; os poderes e prerrogativas de cargos e posições de autoridade e responsabilidade; renda e riqueza, entendidas como meios necessários para atingir seus objetivos; as bases sociais do auto-respeito (cf. J.E.R. p. 83).

Ora, sendo esses os bens primários necessários para o adequado desenvolvimento das pessoas como livres e iguais, os menos favorecidos são os que não têm esses seus bens assegurados ou satisfeitos; são os que não têm sua dignidade protegida. Em outras palavras: se uma sociedade bem-ordenada é aquela em que os direitos e liberdades básicos dos cidadãos estão assegurados e suas oportunidades garantidas de forma eqüitativa, os menos favorecidos são os que têm essas expectativas frustadas ou parcialmente frustradas. Embora usufruam, com os outros cidadãos, das mesmas liberdades básicas iguais, os menos favorecidos "têm a pior renda e riqueza" (J.E.R. p. 92). Ora, de acordo com o segundo princípio, isso é injusto.

Pelo que se pode observar, Rawls, nas revisões de sua "Justiça como Eqüidade”, aponta para uma base histórica das formulações dos princípios da justiça. Os direitos e liberdades fundamentais, indicados no primeiro princípio, são conquistas da história, isto é, estão assegurados nas constituições democráticas mais bem sucedidas. Esse é um argumento forte em favor deles. Não podemos ignorar essa experiência histórica exitosa. Isso mostra que a posição original, caracterizada pelo véu da ignorância, apenas ratifica essas conquistas da história. Os princípios não são formulados como se estivéssemos partindo do grau zero, mas confirma-se o que já é histórica e analiticamente consagrado. "A posição original é um procedimento de seleção" (J.E.R. p. 117). Nela são consideradas as concepções de justiça conhecidas na tradição da Filosofia Política. Poderíamos buscar no sistema hegeliano, sobretudo na Filosofia do Direito, forte apoio para essas idéias.

\subsubsection{O problema da prioridade dos princípios}

Desde as primeiras formulações dos dois princípios da justiça (em Teoria), Rawls insiste na necessidade de que eles devem obedecer a uma "ordenação serial”, devendo o primeiro princípio preceder o segundo. Isso significa que os direitos e liberdades fundamentais precisam ser assegurados e protegidos antes de qualquer aplicação do segundo princípio. Nenhuma vantagem econômica e social pode compensar a violação de uma das liberdades básicas. Portanto, ao falar de prioridade 
da liberdade, o referido autor está falando de uma "ordem lexical”, isto é, da precedência da liberdade igual em relação ao princípio da igualdade eqüitativa de oportunidades e o princípio da diferença. Esse é o primeiro nível de prioridade e critério fundamental para a tomada de decisões. Significa que, efetivamente, é atribuído um status especial às liberdades fundamentais. É essa prioridade que propriamente define um regime democrático liberal. Significa que uma concepção política de justiça protege os direitos fundamentais e lhes atribui uma prioridade especial (cf. L.P. p. 203). A propósito, convêm chamar a atenção para o fato de que o próprio primeiro princípio poderia ser precedido por um outro, o que trata da satisfação das necessidades básicas dos cidadãos, na medida em que a satisfação dessas necessidades seja necessária para que eles possam entender e exercer seus direitos e liberdades fundamentais. No entanto, Rawls, no Liberalismo Político, lembra que essa exigência está pressuposta no primeiro princípio (cf. L. P. p. 47). As medidas a serem tomadas para assegurar as condições materiais suficientes para que os cidadãos possam fazer uso efetivo desses direitos fundamentais estão implícitas no primeiro princípio de justiça. Não se podem exercer os direitos e liberdades básicos sem ter satisfeitas as condições materiais fundamentais. Dignidade e exercício efetivo dos direitos fundamentais mantêm uma relação de reciprocidade. Proteção e promoção da dignidade implica direitos fundamentais assegurados.

Mas, no que se refere à questão da prioridade, há um outro nível que merece destaque. Trata-se dos ajustes a serem feitos em caso de conflitos no efetivo exercício dos direitos e liberdades fundamentais. A solução desses conflitos exige necessariamente o estabelecimento de prioridades. A prioridade não recai sobre cada uma das liberdades tomadas isoladamente, mas sobre "todo o esquema de liberdades básicas" (J.E.R. p. 147). Portanto, é preciso verificar se a restrição de uma liberdade é vantajosa para o sistema total das liberdades.

O assunto é tão complexo que levou Rawls a reformular o primeiro princípio, o que trata dessas liberdades básicas, tanto em Teoria como nas obras posteriores. Se nas primeiras formulações fala em "direito igual ao mais abrangente sistema de liberdades básicas iguais", em formulações posteriores fala em "direito igual ao mais abrangente sistema total de liberdades básicas” (grifo nosso), ou em igual direito a um projeto inteiramente satisfatório de direitos e liberdades básicos iguais (cf. L.P. p. 47). Isso significa que "uma liberdade básica só pode ser limitada ou negada em benefício de outra ou de outras liberdades básicas, e nunca em favor de um bem público maior entendido como um saldo líquido maior de vantagens sociais e econômicas para a sociedade como um todo" (J.E.R. p. 156). A limitação de algum direito fundamental deve fortalecer o "sistema total das liberdades básicas". Está claro, portanto, que a liberdade só pode ser limitada em nome da liberdade (cf. T. J. p. 275).

Ora, ao admitir a possibilidade da restrição, nos termos colocados, estamos dizendo que "nenhuma liberdade básica é absoluta”, tendo em vista que em situações concretas elas podem entrar em conflito e isso exige ajustes. Não se poderia falar em prioridade das liberdades básicas se ajustes e negociações não fossem possíveis.

Uma distinção é oportuna: regular direitos e liberdades não é restringi-los. Para que o exercício efetivo da liberdade de expressão e discussão seja bem sucedido, 
a observância de certas regras de ordem se faz necessária. O debate público, por exemplo, deve ser realizado dentro de certa ordem, onde cada um fala a seu tempo. A prioridade das liberdades básicas, portanto, "não é infringida quando elas são meramente reguladas, como devem ser, para se combinarem num sistema” (L.P. p. 349). A instituição das liberdades fundamentais requer "programação e organização".

Além do mais, falar em liberdades básicas ou fundamentais impõe que se explicite o critério adotado para designar uma liberdade como mais importante do que outra ou para designar um conjunto de liberdades como sendo realmente essenciais. Elas são essenciais em relação a quê? Qual é o critério de importância? O que se quer atingir com o estabelecimento de liberdades realmente fundamentais e sua prioridade?

Rawls reconhece que os critérios adotados em Teoria são insuficientes. Revisões feitas dão conta de que ao estabelecer liberdades básicas e fixar sua prioridade, se quer garantir, de forma igual, para todos os cidadãos, "as condições sociais essenciais para o desenvolvimento adequado e o exercício pleno e informado de suas duas faculdades morais” que são a capacidade de ter senso de justiça e a capacidade de ter uma concepção do bem (J.E.R. p. 158). O senso de justiça diz respeito à aplicação dos princípios da justiça às instituições sociais. As liberdades políticas e a liberdade de pensamento são essenciais para isso. A capacidade de ter uma concepção do bem diz respeito ao "exercício das faculdades da razão dos cidadãos na formulação, revisão e busca racional de tal concepção ao longo de toda a vida” (J.E.R. p. 159). A liberdade de consciência e a liberdade de associação são fundamentais para isso. As outras liberdades básicas, também essenciais, como a liberdade e a integridade da pessoa e os direitos e liberdades garantidas pelo estado de direito, são necessárias para que outras liberdades essenciais sejam garantidas. Portanto, o critério de importância de uma determinada liberdade básica ou de um conjunto de liberdades básicas, agora é claro: "uma determinada liberdade é mais ou menos importante segundo esteja mais ou menos essencialmente implicada no exercício pleno e informado das faculdades morais”, o senso de justiça e a concepção do bem (J.E.R. p. 159). Ou seja, segundo Rawls, uma liberdade é importante ou essencial na medida em que ela é "um meio institucional" necessário para proteger o exercício das faculdades morais. A título de exemplo podemos citar o "direito de ter e fazer uso exclusivo da propriedade pessoal". Por que esse é um direito essencial e como deve ser entendida sua importância? Ele é um direito fundamental porque proporciona "uma base material suficiente para a independência da pessoa e um sentimento de respeito” (J.E.R. p. 160). Sem isso não se desenvolve o senso de justiça e uma concepção do bem. Por isso todas as pessoas têm esse direito. Mas ele não inclui, por exemplo, "a propriedade privada de recursos naturais” e dos "meios de produção”, pois isso não é necessário para o desenvolvimento e exercício das faculdades morais citadas.

É oportuno enfatizar que os referidos ajustes e regulamentações das liberdades fundamentais, tendo em vista a solução de conflitos, têm um objetivo bem claro: visam o "desenvolvimento adequado e pleno exercício das faculdades morais" dos cidadãos, isto é, a capacidade de ter senso de justiça e a capacidade de ter uma concepção do bem. O desenvolvimento dessas capacidades gera estabilidade de uma sociedade e, por conseguinte, a auto-sustentação das instituições políticas e sociais. 
Como se pode observar, não há um tratado de Justiça Penal, em Rawls. No entanto, a regra de prioridade, tal como exposta, indica uma série de critérios para os poderes constitucionais exercerem suas funções, sobretudo o poder judiciário, objeto de exame mais específico nesse trabalho. A discussão básica gira em torno do seguinte tripé: Princípios - Constituição - leis. As leis são justas se constitucionais, ou seja, se concordantes com a Constituição; esta é justa se fundamentada nos princípios que, por sua vez, serão justos se objeto de um consenso na posição original. Donde se conclui que a ausência de leis ou regras, ou a existência de regras duvidosas ou contraditórias para um fato específico, requer o recurso aos princípios de justiça.

Portanto, os princípios de justiça estabelecidos e a regra de prioridade indicada, constituem parâmetros e limites de atuação dos juízes. Em torno deles se circunscreve seu poder de escolha e decisão. A discussão sobre a discricionariedade passa necessariamente pela análise do âmbito daquelas referências.

\subsection{Perelman: Justiça, argumentação e o “auditório universal”}

Perelman, em Ética e Direito, onde estabelece um diálogo com Rawls, parte de uma constatação: inúmeras são as concepções de justiça. Cita e comenta seis das que julga mais correntes: 1 . A cada qual a mesma coisa; 2. A cada qual segundo seus méritos; 3. A cada qual segundo suas obras; 4 . A cada qual segundo suas necessidades; 5. A cada qual segundo sua posição; 6 . A cada qual segundo o que a lei lhe atribui (cf. E.D. p. 9). ${ }^{9}$

Entre as várias atitudes possíveis diante dessas concepções, o referido autor trata de encontrar uma concepção de justiça que seja comum às seis formulações citadas. É o que chama de justiça formal: "seres de uma mesma categoria essencial devem ser tratados da mesma forma” (E.D. p. 19) ${ }^{10}$ ou, é preciso observar a regra que "enuncia a obrigação de tratar de certa maneira todos os seres de uma determinada categoria” (p. 45). Esse é o elemento comum a todas as formulações de justiça referidas. No entanto, a justiça formal não pode ser reduzida à aplicação correta de uma regra, mas à aplicação de uma regra justa. A dificuldade está em estabelecer o critério de justiça de uma regra. A resposta está no princípio que a fundamenta, como veremos. A teoria da justiça de Rawls, tal como desenvolvida, não tem outro objetivo a não ser indicar os princípios orientadores para a estrutura básica da sociedade, isto é, as principais instituições sociais. Portanto, são princípios reguladores para todas as tomadas de decisão. São os critérios de justiça.

Diante da concepção de justiça formal apresentada, podemos deduzir que um ato será formalmente justo se estiver de acordo com uma regra que manda tratar de certa maneira todos os seres de uma determinada categoria. Mas dizer que um ato é formalmente justo é diferente do que dizer que uma regra é justa. Um ato é formalmente justo quando está de acordo com a lei. A regra é justa se estiver de acordo com o princípio que a fundamenta. Mas se ela for injusta, como proceder? É sempre possível, como alerta Perelman, escapar à injustiça formal, através da

${ }^{9}$ O intuito aqui não é caracterizar cada uma dessas concepções, mas apenas desenvolver as idéias de Perelman a partir de elementos comuns nelas identificados.

${ }^{10}$ A propósito, Rawls não gosta da expressão “justiça formal”; prefere “justiça como regularidade” (T.J. p. 257) 
modificação da regra. Logo, não podemos reduzir a concepção de justiça à justiça formal. Isso seria reduzi-la ao princípio do precedente. Ora, em nome da justiça é preciso, às vezes, afastar-se do precedente, sobretudo tendo em vista conseqüências desastrosas decorrentes de sua aplicação.

Aqui está o grande desafio de uma teoria da justiça: a justificação de uma regra, com princípios orientadores e fundamentadores, sobretudo, quando os juízes se afastam dela. Toda mudança precisa ser justificada, e por boas razões.

Segundo Perelman, uma regra é arbitrária quando "não for suscetível de justificação” (E.D. p. 56). E o que é justificar uma regra particular? É mostrar como ela se deduz de uma regra mais geral ou "como uma determinada categoria se integra numa categoria mais vasta” (p. 57). Ora, considerando que um sistema de justiça é um sistema normativo, uma regra normativa é justificada mostrando-se como ela está fundamentada em princípios mais gerais. Mas como fundamentar estes? Todos os princípios estabelecem valores. ${ }^{11}$ Dizer, então, que os princípios são justos implica na justificação desses valores. Ora, reconhece Perelman, valores são sempre arbitrários. Exigem-se escolhas. Daí a necessidade de sua justificação e o critério é que esta obtenha a concordância do "auditório universal”, constituído pelas mentes razoáveis e bem informadas ou pelos "homens normais e competentes" (E.D. p. 202 e 399). Rawls dirá que as regras são justas se estiverem de acordo com a Constituição, que será justa se contemplar os princípios da justiça que, por sua vez, serão justos se forem objeto de um consenso na posição original, constituídos por pessoas éticas, isto é, as que têm senso de justiça e uma concepção do bem, portanto pessoas que podem desenvolver e exercer suas capacidades morais. Um sistema normativo, afirma Perelman, que é diferente de um sistema lógico, contém sempre um elemento arbitrário: o valor afirmado por seus princípios fundamentais (cf. E.D. p. 67). Isso mostra que tanto princípios quanto regras são normativas. Ora, dado esse caráter arbitrário dos valores que fundamentam esse sistema normativo, e por mais bem justificados que sejam, não há sistema normativo necessário e perfeito; não há justiça absoluta. Uma concepção política de justiça, ou seja, uma concepção de justiça limitada ao domínio do político, que não é uma teoria moral abrangente, certamente torna o recurso aos princípios e valores menos arbitrário.

Podemos resumir o que até aqui dissemos no seguinte tripé: regras, princípios e valores. Regras são justificadas pelos princípios; princípios são fundamentados pelos valores que os constituem e estes são justificados pelos argumentos que podem receber o acordo do auditório universal, isto é, por valores que sejam universalizáveis.

Esse recurso à justificação e à argumentação amplia a concepção de justiça para além da justiça puramente formal.

Voltemos à regra da justiça: é justo tratar da mesma forma o que é essencialmente semelhante. A aplicação dessa regra evidencia, em primeiro lugar, a importância do precedente (é preciso considerar o tratamento anterior de uma situação semelhante). Diz mais: só é possível afastar-se do precedente mediante a apresentação de fortes razões.

${ }^{11}$ Rawls restringe sua Teoria aos valores políticos, considerando que sua concepção de justiça é política. Não haveria consenso possível se se tratasse de uma concepção moral abrangente. 
No entanto, o problema da justificação não está na aplicação da regra às situações iguais ou até mesmo semelhantes, mas está nos casos difíceis ou na mudança do precedente, pois sua aplicação teria conseqüências injustas. Toda mudança e só a mudança precisa ser justificada (princípio da inércia), apelando aos recursos da argumentação. Essa argumentação será racional na medida em que for "válida para um auditório universal, constituído pelo conjunto das mentes razoáveis” (E.D. p. 94). A justificação implica num apelo à razão que, para Perelman, é um "auditório privilegiado”, o "auditório universal”, na tentativa de convencer os membros desse auditório, através do discurso, da argumentação. Em Habermas, essa é a função do “princípio de universalização". ${ }^{12}$ Essa perspectiva foge da concepção de justiça formal. A regra da justiça (tratar da mesma forma seres em situações semelhantes) atende a concepção formal de justiça, isto é, atende ao princípio do precedente, que assegura a continuidade e a coerência, mas não satisfaz a mudança. Boas razões exigem a mudança. Ora, é nisso que está o intuito de um sistema normativo: a possibilidade de efetivamente praticar a justiça recorrendo aos princípios e valores concordantes com o auditório universal, mesmo que para isso se tenha que reinterpretar a lei e mudá-la. Se somente a mudança deve ser justificada ela deve ser corajosamente feita para evitar conseqüências absurdas com a aplicação do precedente. O princípio da inércia, o de que não se deve mudar nada sem razão, continua sendo válido, mas se deve, e positivamente falando, mudar quando há boas razões. E são as razões que importam. Aí está o caráter arbitrário de um sistema de justiça, e ele não seria normativo se não fosse arbitrário. Ele indica um dever-ser e não simplesmente justifica o que é. E isso implica em escolhas. É nas boas razões, no recurso ao razoável, na argumentação e justificação de acordo com o auditório universal que é possível realizar a verdadeira justiça.

É por isso que o raciocínio do juiz, ao servir-se de seu poder de interpretação, não é e não pode ser puramente formal. Levando em conta as conseqüências, reinterpreta o texto da lei que tem a missão de aplicar. Seu raciocínio, sustenta Perelman, é dialético e não analítico, como é o dos matemáticos. Nesse caso a função do juiz é análoga a do filósofo. Suas soluções apresentadas às questões debatidas "só poderiam pretender-se razoáveis na medida em que são submetidas à aprovação do auditório universal, constituído pelo conjunto dos homens normais e competentes para julgá-las” (E.D. p. 399). Nesse sentido, se pode dizer que a justiça tem tudo a ver com a razoabilidade. O razoável, diz Perelman, "se elabora mercê do concurso de todos os seres humanos suscetíveis de se integrarem no auditório universal e necessita do confronto de idéias, do conhecimento de suas reações efetivas” (p. 399). O razoável é o critério de conduta e das normas práticas; remete não a uma "razão invariável” mas a "situação puramente humana” (p. 399). ${ }^{13}$

\section{REGRAS E PRINCÍPIOS}

Referidas as concepções de justiça e seus princípios orientadores, cumpre estabelecer algumas distinções entre princípios e regras, tendo em vista o poder de

\footnotetext{
12 Ver “Consciência Moral e Agir Comunicativo”, p. 147. Podemos, também, considerar o auditório universal como uma espécie de "comunidade ideal de comunicação” ou "comunidade interativa ideal” (ideale kommunikative Gemeichaft), nos termos de Apel.

${ }^{13}$ Sobre a distinção entre o racional e o razoável, em Rawls, ver O Liberalismo Político, p. 92.
} 
interpretação e decisão dos juízes.

A discussão em torno do poder discricionário aparece em Dworkin, sobretudo, quando estão em jogo decisões que envolvem os casos difíceis. ${ }^{14}$ Nesses casos, os juristas "recorrem a padrões que não funcionam como regras, mas operam diferentemente, como princípios, políticas e outros tipos de padrões” (L.D.S p. 360). A distinção, portanto, entre regras, princípios e políticas é imprescindível para o debate em torno do poder discricionário. Precisamos saber se os princípios são parte constitutiva do Direito ou se são recursos extralegais. Liberais e positivistas dividem-se quanto a esse assunto.

A distinção entre princípios e políticas nem sempre é clara. Muitas vezes se confundem. Dworkin os distingue da seguinte forma: "Denomino política aquele tipo de padrão que estabelece um objetivo a ser alcançado, em geral uma melhoria em algum aspecto econômico, político ou social da comunidade. Denomino princípio um padrão a ser observado, não porque vá promover ou assegurar uma situação econômica, (...) mas porque é uma exigência de justiça ou equidade” (p. 36). Um exemplo é esclarecedor: “o padrão que estabelece que os acidentes automobilísticos devam ser reduzidos é uma política e o padrão segundo o qual nenhum homem deve beneficiar-se de seus próprios delitos é um princípio” (L.D.S. p. 36).

O objetivo do referido autor, no entanto, é distinguir princípios e regras. Dois exemplos são esclarecedores: $1^{\circ}$ - Um tribunal de Nova Iorque teve que tomar uma decisão: um herdeiro nomeado num testamento por seu avô deve receber o que está nele previsto, mesmo que o tenha assassinado para beneficiar-se desse testamento? É o famoso caso de 1889, “Riggs contra Palmer”. Levando em consideração o princípio (do Direito costumeiro) segundo o qual "ninguém pode beneficiar-se com seus próprios atos ilícitos”, os juízes decidiram que o assassino não deveria receber a herança prevista. O Tribunal argumentou que leis e contratos podem ser limitados, na sua execução, pelo Direito Costumeiro. $2^{\circ}$ - Outro exemplo comentado por Dworkin é o caso de "Hennigsen contra Bloomfield Motors", de 1969, onde um Tribunal de Nova Jérsei deu decisão favorável à Hennigsen em relação à responsabilidade do fabricante do seu carro. O que estava em jogo é o limite da responsabilidade do fabricante para além de casos defeituosos do veículo. Embora o contrato assinado previsse apenas o reparo das partes defeituosas, o reclamante entendeu que, em seu caso, o fabricante deveria ser responsabilizado pelas despesas médicas e outros danos resultantes de uma colisão. Embora não encontrasse uma lei ou uma regra do Direito "que proibisse o fabricante de insistir nos termos do contrato” (L.D.S. p. 38), o Tribunal concordou com o autor da ação. Alegou que os fabricantes de carros têm uma obrigação especial no que se refere à fabricação, promoção e venda de seus carros (cf. L.D.S. p. 38).

Nos dois casos os juízes decidiram em nome de princípios e não em nome de regras jurídicas. O padrão tomado como referência é diferente do que diz uma regra.

\footnotetext{
${ }^{14}$ Casos difíceis são aqueles em que há incerteza, ou porque há normas contraditórias ou porque não existe norma aplicável. Podemos incluir, também, as situações em que a validade da lei é duvidosa. Nesses casos requer-se a aplicação de princípios. É oportuno acrescentar que os casos mais fáceis (simples) são decididos pela aplicação de regras (tudo ou nada).
} 
Por exemplo: a regra que estabelece a velocidade máxima de $80 \mathrm{~km} / \mathrm{h}$ é muito mais específica do que um princípio, como os citados. A rigor, a diferença não se refere tanto ao caráter normativo das regras e princípios, pois ambos, de alguma forma, o têm. (É claro que existem princípios que são mais valorativos do que prescritivos). A distinção está, principalmente, no grau de generalidade. Esse é, em todo caso, o critério no qual Dworkin mais insiste. ${ }^{15}$

Além disso, a diferença entre princípios jurídicos e regras jurídicas "é de natureza lógica”. A natureza da orientação que oferecem é diferente: a regra é aplicável “à maneira tudo-ou-nada”; a regra ou é válida ou não é válida. Isso não acontece com os princípios. Eles não apresentam conseqüências jurídicas automáticas, dadas certas condições. Mesmo que exista o princípio segundo o qual ninguém pode beneficiar-se de seus erros, há muitas pessoas que se beneficiam dos erros que cometem. Um exemplo clássico é o caso do usucapião: se atravesso as terras de alguém sem autorização por muito tempo, passo a adquirir o direito de fazê-lo quando bem desejar. Os princípios, "nenhum homem pode beneficiar-se de seus próprios delitos" e "o fabricante tem uma obrigação especial em relação à fabricação de seus carros”, não têm uma aplicação imediata; requerem uma decisão particular. Eles estabelecem um padrão de conduta; enunciam uma direção de comportamento.

Além disso, há princípios que apresentam uma diferença ainda maior em relação às regras. Voltemos ao exemplo citado: o fabricante tem uma obrigação especial em relação à fabricação de seus carros. Não há definição de deveres específicos. O princípio dá uma orientação geral que requer, na aplicação, interpretação. Não é o que ocorre com uma regra. Ela tem ou não tem aplicação imediata. São normas na base de tudo ou nada.

Outra diferença entre princípios e regras refere-se ao seu grau de importância. Quando há conflitos de princípios é preciso examinar a força dos argumentos que podem ser aduzidos em favor de cada um. Ambos podem continuar valendo, mesmo que no caso específico um deles seja mais razoável do que outro. Em havendo conflito de regras, a situação muda: uma delas não pode ser válida. Para saber qual das regras é válida deve-se recorrer a considerações que vão além delas, isto é, aos princípios que as fundamentam.

Como dissemos, é nos casos difíceis ou nas questões judiciais difíceis que os princípios têm um papel fundamental. É neles que são baseados os argumentos que sustentam as decisões dos juízes a respeito de direitos e deveres particulares.

Quando não há regras ou quando elas são controversas, os tribunais recorrem aos princípios para justificar a adoção e a aplicação de novas regras (cf. L.D.S. p. 46). No caso do testamento, e para negar a herança, o tribunal tomou como base o princípio segundo o qual "ninguém pode beneficiar-se de seus próprios delitos” como parâmetro básico para justificar uma nova interpretação da lei dos testamentos. Observa-se, claramente, a importância que assumem os princípios quando da formulação e justificação das decisões jurídicas particulares. Logo, assim como as regras, também

${ }^{15}$ Sobre a distinção entre princípios e normas, ver livro de Ricardo Guastini, Distinguiendo. Estudos de teoría y metatoría del derecho, cap. V. 
os princípios são normativos. O grau de abrangência, obviamente, é diferente. Para Dworkin as regras fundamentam-se em princípios e estes fazem parte do Direito e não são recursos extralegais. Além do mais, estabelece uma íntima relação entre questões morais e questões jurídicas. Divergem os positivistas, sobretudo Kelsen, que defende uma "teoria pura do Direito".

Se mudarmos um pouco o foco da discussão e perguntarmos pela justiça das regras e princípios podemos observar, além das distinções, também a sua inter-relação.

Para Perelman, em Ética e Direito, uma regra é justa quando não é arbitrária. E ela não é arbitrária na medida em que pode ser justificada por princípios mais gerais (cf. E.D. p. 181). Ou seja, a arbitrariedade de uma regra é eliminada quando da justificação. Aliás, justificação não pode ser confundida com demonstração. Esta se desenvolve a partir de enunciados e proposições, que são verdadeiros ou falsos. A justificação é de ordem prática: "justifica-se um ato, um comportamento (...) uma escolha, uma decisão” (E.D. p. 185).

Estamos aqui falando de justificação das regras e não de demonstração de proposições. Justificar uma determinada regra, portanto, é mostrar como ela se deduz de uma regra mais geral (cf. E.D. p. 57). "A justificação de uma regra normativa apela a um princípio mais geral” (E.D. p. 57). Mas como justificar os princípios? Segundo o autor em pauta, os princípios mais gerais determinam o que vale, isto é, "estabelecem um valor, o valor mais geral, do qual se deduzem as normas, os imperativos, as ordens” (E.D. p. 58). Mas como não resulta de uma necessidade lógica, esse valor tem um caráter de arbitrariedade. Este conceito de arbitrariedade não pode ser tomado no sentido pejorativo, mas no sentido de que quando falamos em valores estamos falando de escolhas e estas requerem justificação, argumentação. É oportuno observar que quando se trata de um sistema de justiça, por mais justificado que seja, não temos como eliminar toda arbitrariedade. Pois é exatamente essa arbitrariedade dos valores que caracteriza um sistema normativo. Se assim não fosse, não seria normativo. Diria o que é e não o que deve ser. Um sistema normativo indica o que deve ser e não o que é. Dizer o que é é estabelecer uma necessidade lógica (matemática) e não uma ordem prática.

Portanto, todo sistema de justiça - como há muitos valores há vários sistemas tem sua base de sustentação nos princípios, e como estes se constituem ou estabelecem valores, todo sistema de justiça depende dos valores que seus princípios estabelecem (cf. E.D. p. 62). Segundo o autor, a justiça se constitui de um valor próprio: "é aquele que resulta do fato de sua aplicação satisfazer a uma necessidade racional de coerência e de regularidade” (p. 63). Mas apesar dessa coerência e regularidade, o caráter arbitrário dos valores que fundamentam um sistema jurídico faz com que um sistema de justiça perfeito seja impossível de ser realizado. "Nenhuma decisão jurídica é necessariamente uma decisão correta”, afirma Dworkin, e continua, "os juízes representam diferentes posições quanto a questões controversas de direito e da moral” (L.D.S. p. 285).

Mas quais seriam os princípios gerais do direito e da justiça e como se formulam? Antes de tudo é preciso dizer que eles "exprimem valores tradicionais na consciência jurídica de uma civilização dada, formulam eles teses que os membros 
educados da sociedade são tentados a admitir espontaneamente, por isso, aproximam-se mais de princípios evidentes que não necessitam muito de uma autoridade particular para serem admitidos” (E.D. p. 380). Estão inscritos no “espírito do tempo”, diria Hegel. Nesse contexto, segundo Perelman e outros autores, a dignidade da pessoa humana é o princípio geral do direito. Ele é uma conquista da história. Escreve o autor: “o respeito pela dignidade da pessoa humana é considerado hoje o princípio geral do direito comum a todos os povos civilizados” (E.D. p. 401). É esse princípio que fundamenta uma doutrina dos direitos humanos. A rigor, todas as regras precisariam ter como fundamento último este princípio: a dignidade da pessoa humana. Ele se constitui como valor fundamental. Kant é o grande expoente desse princípio. ${ }^{16}$

Os princípios da justiça de J. Rawls nada mais são do que a expressão desse valor. São objeto de um acordo na "posição original”; não são simples intuições, mas são encontrados na tradição da filosofia política ocidental. Análogas ao imperativo categórico de Kant, são idéias reguladoras e orientadoras das instituições jurídicas e sociais. Servem, portanto, de critério para as tomadas de decisão. Estão presentes nas constituições das democracias mais bem sucedidas da nossa história política. São princípios políticos e não morais e/ou religiosos. Incluem valores, mas valores políticos. As leis são justas se concordantes com a Constituição, que será justa se regulada pelos princípios da “justiça como eqüidade”, que são objeto de um acordo na posição original (enquanto procedimento de seleção). Daí a sua universalidade. É o que tem em comum a posição original e o auditório universal. A autonomia das partes está assegurada e é o que legitima os princípios. Suportar o teste da universalização e do reconhecimento continua sendo um aspecto fundamental dessa legitimação.

\section{O PODER DISCRICIONÁRIO (DWORKIN E PERELMAN)}

A distinção entre regras e princípios é fundamental para a discussão do problema do poder discricionário. A importância dessa discussão se evidencia, sobretudo, nos chamados casos difíceis ou questões judiciárias difíceis, como os casos Riggs e Hennigsen, ou quando é necessário mudar o precedente. Os casos simples são resolvidos pela aplicação de regras. Os princípios dão sustentação aos argumentos desenvolvidos pelas decisões dos juízes no que se refere aos "direitos e obrigações jurídicas particulares” (cf. L.D.S. p. 46). Os tribunais citam os princípios para justificar a adoção de uma regra. Daí sua importância.

O problema do poder discricionário dos juízes está diretamente ligado à resposta que é dada às seguintes questões: Os princípios são parte do Direito assim como as regras, e os juízes devem levá-los em conta nas decisões sobre obrigações jurídicas, ou os princípios são extralegais, indo além do Direito, e os juízes têm a liberdade de aplicá-los ou não? Os princípios obrigam da mesma forma como as regras? O juiz, quando decide nos casos difíceis, vai além do Direito, lançando mão de princípios

${ }^{16}$ Ver segunda seção da Fundamentação da Metafísica dos Costumes, onde são tratadas as formulações do imperativo categórico. O tema da dignidade da pessoa humana é explicitamente referido na formulação que trata do homem como fim em si mesmo e a que discorre sobre o "reino dos fins", onde é central o conceito de autonomia. Ver, também, Ingo Sarlet e a vasta bibliografia citada sobre esse assunto em Dignidade da Pessoa Humana e Direitos Fundamentais na Constituição de 1988, Porto Alegre: Livraria do Advogado, 2004 
extralegais? Qual é, propriamente, a relação entre princípios e regras, quando está em discussão o poder discricionário? Existe esse poder?

Antes de responder essas questões voltemos a uma questão conceitual: o que é poder discricionário? Justificar escolhas recorrendo aos valores, argumentar em favor da mudança do precedente, não é uma forma de poder discricionário ou isso é próprio da hermenêutica jurídica?

Dworkin discute o tema a propósito de sua crítica ao positivismo. Segundo ele, “os positivistas sustentam que quando um caso não é coberto por uma regra clara, o juiz deve exercer seu poder discricionário para decidi-lo mediante a criação de um novo item de legislação” (L.D.S. p. 50). Ora, essa tese dá claramente a entender que os juízes têm uma função legisladora, criadora e não só julgadora e garantidora de direitos. Aqui está o ponto de divergência. A legislação depois dos fatos é o grande problema.

Para Dworkin, o conceito de poder discricionário deve ser colocado no seu devido contexto; ou seja, alguém tem poder discricionário quando deve "tomar decisões de acordo com padrões estabelecidos por determinada autoridade" (L.D.S. p. 50). Portanto, o exercício desse poder sempre diz respeito a certos padrões que estão dentro de um contexto.

O referido autor parte da linguagem ordinária para distinguir dois sentidos fracos do conceito de "poder discricionário" e um sentido forte. Os sentidos fracos referem-se basicamente a tomadas de decisão de acordo com padrões estabelecidos por uma autoridade, ou porque isso não pode ser feito mecanicamente e exige o uso da "capacidade de julgar” ou porque está em jogo uma "hierarquia de servidores", onde uns têm mais autoridade do que outros e a decisão da maior autoridade é definitiva e não pode ser revista. Mais especificamente, segundo o primeiro sentido fraco "um homem tem poder discricionário se seu dever for definido por padrões que pessoas razoáveis podem interpretar de maneiras diferentes” (L.D.S. p. 109). De acordo com o segundo sentido fraco, um homem tem poder discricionário na medida em que sua decisão for definitiva. Ele é a autoridade máxima e sua decisão não pode ser revista. Transferindo isso para o âmbito jurídico, o primeiro sentido ocorre nos casos em que, não havendo a exigência de nenhuma "regra social", no que se refere a uma decisão jurídica específica e havendo dúvida por parte dos “membros da profissão jurídica” sobre a decisão a ser tomada, devem os juízes decidir. Devem tomar uma iniciativa que vá além da aplicação de uma regra dada. Se esses juízes compuserem a última instância de recursos, teremos o poder discricionário no segundo sentido.

É no sentido forte de poder discricionário (terceiro) que Dworkin se detém, por considerar que os positivistas o entendem nesse sentido. Para o autor, ter poder discricionário em sentido forte é não estar limitado pelos padrões de autoridade, pelo menos em certos assuntos. Em outras palavras, um homem tem poder discricionário quando seus deveres de tomar uma decisão não estão submetidos a certos padrões ou quando um conjunto de padrões não objetiva o dever de tomar uma decisão específica (cf. L.D.S. p. 109). Dworkin aceita que os juízes tenham poder discricionário nos dois 
primeiros sentidos, mas não no terceiro (sentido forte). A doutrina positivista argumenta, segundo análise do autor, que "se um caso não for regido por uma regra estabelecida, o juiz pode decidi-lo exercendo seu poder discricionário” (p. 54). Ou seja, quando o juiz esgota as regras disponíveis, não está obrigado por padrões derivados da autoridade da lei, que seria o caso do recurso aos princípios e valores (que seriam extralegais para os positivistas) (cf. L.D.S. p. 55). Se não está limitado por padrões, como os princípios e os valores, o juiz tem, na tradição positivista, poder discricionário para criar regras onde elas não existem ou são contraditórias.

É nesse sentido forte que Dworkin examina o poder discricionário. Sua posição é clara. Na ausência de regras ou diante de regras contraditórias o recurso do juiz deve ser aos princípios e valores, considerando que são parte constitutiva e essencial do Direito, mas que, também, podem ser não jurídico-positivos. Regras fundamentam-se em princípios e o juiz, portanto, não tem poder discricionário. Na ausência de regras, não está livre de "padrões jurídicos e morais”, que são parte do Direito. Não se pode dar liberdade ao juiz para decidir arbitrariamente os casos difíceis. Ele não está legitimado para ditar regras. O que se deve exigir dele é a busca de critérios e uma fundamentação que justifique as decisões tomadas. Ora, essa fundamentação deve dar-se a partir dos princípios. ${ }^{17}$ Nas lacunas ou contradições das regras, o juiz está determinado pelos princípios porque eles fazem parte do Direito e não são extralegais, como dão a entender os positivistas. A função do juiz é garantidora de direitos e não criadora dos mesmos. Se os princípios fazem parte do Direito cabe ao juiz justificar os princípios e valores escolhidos. Mas estes já existem na tradição do Filosofia Política ou do Direito Costumeiro. ${ }^{18}$ Logo, não há poder discricionário. Nos casos de ausência de regras ou regras duvidosas, o recurso aos princípios é próprio da hermenêutica jurídica. É que Dworkin estabelece uma íntima ligação entre questões morais e questões jurídicas. Mostra como as posições morais fornecem a base para “argumentos constitucionais” (cf. L.D.S. p. 319). “A Constituição funde questões jurídicas e morais, fazendo com que a validade de uma lei dependa da resposta a problemas morais complexos ... (L.D.S. p. 285). Nesse caso, Rawls é mais restritivo. Apresenta um construtivismo político e não moral, como o de Kant. Seus princípios de justiça, como vimos, constituem uma concepção política e não uma doutrina moral abrangente. Os cidadãos gozam de uma autonomia política e não ética. É importante insistir que, para Dworkin, os princípios podem ser não jurídico-positivos, posição não aceita pelos positivistas. O positivismo não aceita uma fundamentação do Direito na Moral.

No texto sobre A idéia da razão pública, Rawls apresenta o Supremo Tribunal como exemplo de "razão pública” (cf. L.P. p. 281). Considerando tratar-se de uma concepção política de justiça, para ele os juízes terão que pautar-se apenas em

${ }^{17}$ Está pressuposto, aqui, que se aceite a distinção entre regras e princípios. Também não está em discussão se a crítica de Dworkin ao positivismo é justa. Isso merece outro estudo. Cabe apenas observar que, segundo alguns críticos, Dworkin não percebeu que para os positivistas os princípios são normas gerais e se engana ao afirmar que não há princípios no positivismo. (Cf. Gomes, Alexandre. A Moral e o Direito em Kant. Ensaios Analíticos, pp. 162 e 167).

${ }^{18}$ Segundo Rawls, os princípios de justiça, objeto de um acordo na posição original, são escolhidos a partir de uma lista oferecida às partes e encontradas entre as mais importantes concepções de justiça política da nossa tradição de Filosofia Política (cf. J.E.R. p. 117). 
valores de "índole política". Nesse contexto, considera a concepção de "moralidade como tal" e mesmo de "moralidade política" de Dworkin ampla demais, sobretudo quando trata do que os juízes podem invocar em suas interpretações da Constituição. Para Rawls, "os juízes, ao interpretar a Constituição, devem apelar para os valores políticos abrangidos pela concepção política e pública de justiça”. [...] "Os valores que os juízes podem invocar restringem-se ao que é razoável acreditar ser parte dessa concepção ou de suas variantes, e não parte de uma concepção de moralidade como tal, nem mesmo de moralidade política” (L. P. p. 287). Essa restrição ao domínio do político é decisiva para possibilitar o acordo em torno dos princípios de justiça e, consequentemente, legitimar a atuação dos poderes constituídos.

Um positivista poderia dizer, segundo Dworkin, que os princípios não podem obrigar. Essa tese é rechaçada pelo autor sustentando que de fato pode ser questionado se um princípio realmente obriga algum juiz, mas "não há nada no caráter lógico de um princípio" que o torne incapaz de obrigar uma autoridade jurídica. No caso Henningsen, o juiz tinha o dever de levar em consideração o princípio segundo o qual os fabricantes de automóveis têm uma obrigação especial para com seus consumidores. $\mathrm{O}$ autor da ação (o acidentado Hennigsen) tem o direito de esperar que o juiz leve em consideração aquele princípio vigente na comunidade política. Por ocasião da guerra do Vietnã, os protestos contra o recrutamento, nos anos 60, tinham um caráter claramente moral, segundo avaliação do autor, e que foram reconhecidos pelos juristas americanos para formarem a base de muitos argumentos constitucionais. ${ }^{19}$ Portanto, na medida em que estão sujeitos aos "padrões jurídicos e morais" (princípios e valores), os juízes não têm poder discricionário. Mas a vinculação aos princípios e valores lhes exige escolha, interpretação e justificação.

Dworkin afirma com acerto que "é tautológica a proposição segundo a qual, quando não há regra clara disponível, deve-se usar o poder discricionário para julgar” (L.D.S. p. 55). Pois, considerando que toda regra fundamenta-se em algum princípio, é a este que os julgadores devem recorrer. Em não havendo regras claras, há princípios. Mas o recurso a eles não é poder discricionário. Os princípios são normativos e, tal como as regras, constituem parte essencial do Direito e da justiça. ${ }^{20}$

Um outro aspecto diz respeito ao resultado. Um positivista poderia dizer que os princípios não prescrevem resultados. O que são resultados? São soluções práticas imediatas? Ora, princípios não são regras. Aqueles não apresentam resultados imediatos, mas é exatamente isso que os distingue das regras. A rigor, somente as regras ditam resultados. Mas também é verdade que um resultado contrário a uma regra exige a sua mudança. No caso dos princípios não é assim. É perfeitamente possível que princípios divergentes continuem valendo. Essa divergência não lhes tira o caráter prescritivo, embora sejam mais abrangentes do que as regras. É que eles indicam uma direção, um padrão a ser observado, o que deve ser, dão uma orientação, mas não de forma conclusiva. Requerem interpretação (e adaptação). Mas isso não significa

\footnotetext{
${ }^{19}$ Ver discussão no capítulo sobre a desobediência civil, em Levando os Direitos a Sério, do mesmo autor. ${ }^{20}$ Devo ao Prof. Dr. Carlos Molinaro (PUCRS) um rico debate sobre o caráter prescritivo de princípios e regras.
} 
dizer que os juízes, mesmo recorrendo aos princípios, tenham poder discricionário. Embora obriguem de forma diferente do que as regras, como foi observado, os princípios fazem parte do Direito.

Para um positivista, os princípios não podem valer como leis. Isso mostra que para ele os princípios vão além do Direito (ciência jurídica). São apenas padrões morais ou políticos. É o que indica a teoria pura do Direito do neokantiano e formalista Kelsen. Ele desenvolve um sistema de Direito separado do contexto não-jurídico. A moral está separada do Direito. Não aceita, portanto, qualquer fundamentação do Direito na Moral.

Mas quando, então, pode o juiz mudar uma regra do Direito em vigor? Para Dworkin, os princípios aparecem de duas maneiras: $1^{\circ}$ - É necessário que o juiz leve em conta que toda mudança de uma lei deve favorecer algum princípio. "O princípio justifica a modificação” (L.D.S. p. 60). A aplicação pura e simples da regra em certos casos, conduziria a graves injustiças. No caso Biggs, a lei dos testamentos foi mudada e justificada com base no princípio segundo o qual "nenhum homem pode beneficiar-se de seus atos ilícitos”. Dworkin salienta que não é qualquer princípio que justifica a mudança de uma lei. Existem princípios mais importantes e outros menos importantes. Mas isso não depende, pura e simplesmente, das preferências do juiz. A rigor, nenhuma regra seria, então, mais válida. Cada um poderia recorrer a padrões extrajurídicos para apresentar sua fundamentação, de acordo com suas preferências. $2^{\circ}$ Para justificar as mudanças o juiz deve também considerar alguns padrões importantes que se opõem ao abandono de doutrina estabelecida. Esses padrões são princípios (cf. L.D.S. p. 60). Aspectos fundamentais incluídos por esses padrões são a doutrina do precedente e a "supremacia do Poder Legislativo". Ambos incluem princípios. Perelman insiste na doutrina do precedente como sendo a regra da justiça. Em vista disso, toda mudança precisa ser justificada diante do auditório universal. Os juízes precisam levar em conta os princípios que constituem a doutrina do precedente e a supremacia do poder legislativo. Não se pode fazer tabula rasa do passado intelectual. Isso seria opor-se ao princípio da inércia, que se manifesta pela regra da justiça, pela conformidade com o precedente.

Dizer, portanto, que uma regra é obrigatória significa sustentar que está fundamentada em princípios, princípios esses que os tribunais não podem desconsiderar. Isso vale tanto para justificar uma mudança quanto para manutenção de uma regra. Para mudar é preciso primeiro considerar os princípios que compõem o precedente e a supremacia do poder legislativo. A mudança pode não ser justificada exatamente por causa desses princípios, que Dworkin chama de "princípios conservadores" (L.D.S. p. 61). Os juízes não têm liberdade de ignorar esses princípios. Escolhê-los e interpretá-los é sua função. Isso assegura continuidade e coerência. Indica, mais uma vez, que eles não têm poder discricionário (em sentido forte). Existem padrões a serem considerados. Para mudar regras devem recorrer a princípios; para justificar os princípios através de valores, não devem desconsiderar a doutrina do precedente. Isso, no entanto, não significa que não possam, em vista das conseqüências, decidir contrariamente ao precedente, mas, como diz Perelman, devem dar boas razões para isso; e boas razões são as que têm a concordância do auditório universal, constituído 
pelas mentes razoáveis e bem informadas. E homens razoáveis fundamentam seus princípios em valores universalíssimos ou universalmente reconhecidos. Significa que os juízes podem, em nome de princípios universalmente aceitos, não aplicar leis injustas.

Tanto Dworkin quanto Perelman e Rawls admitem conflitos entre princípios. Mas a solução desses não está, pura e simplesmente, no poder de decisão do juiz. Está na justificação do princípio escolhido que, para aquele caso, tem força de convicção. Rawls insiste na regra da prioridade dos princípios, estabelecendo uma ordem léxica ente eles. E, como vimos, há critérios para isso. A tarefa do juiz está na justificação racional da decisão tomada em favor do princípio ou dos princípios escolhidos. Se os princípios, assim como as regras, fazem parte do Direito, não cabe ao juiz poder discricionário para criar regras, mas a justificação do ou dos princípios escolhidos quando da ausência de regras estabelecidas para determinada situação, ou mesmo quando forem contraditórias. Nesse caso, fica claro que os juízes não têm obrigação de aplicar leis injustas. Especificamente, para Dworkin, o juiz não é legislador, mas seu poder é o de garantir direitos, justificando suas decisões de acordo com princípios e valores universalmente reconhecidos. Para o autor, a insuficiência do positivismo, ao defender o poder discricionário, está no fato do juiz tornar-se legislador ex post facto.

Em resumo, regras ficam arbitrárias quando não justificadas. Sua justificação se dá através do recurso aos princípios, que são elementos constitutivos do Direito. A escolha e a fundamentação desses, por parte dos juízes, se dá pela força da argumentação e pelo convencimento do auditório universal. Quando ocorrem conflitos entre princípios, não se pode deixar o assunto nas mãos discricionárias dos juízes. Estes devem escolher o princípio que tenha maior força de argumentação. A função dos juízes consiste na justificação racional do princípio escolhido.

\section{O PODER DISCRICIONÁRIO DOS JUÍZES E O AUDITÓRIO UNIVERSAL}

Tema recorrente no debate entre positivistas e liberais, e com profundas divergências, é o poder discricionário dos juízes. A discussão gira, basicamente, em torno dos limites de atuação e decisão dos mesmos. Devem os juízes apenas aplicar a lei ou devem colaborar em sua elaboração? Até que ponto estão presos a uma ordem legal previamente constituída? A questão se coloca principalmente, como vimos, nos chamados casos difíceis. Ou seja, quando não há regras claras ou quando elas são contraditórias, ou até mesmo quando são duvidosas, nos termos de Dowrkin, como devem proceder os juízes? Podem recorrer a princípios ou estes estão fora de uma “teoria pura do Direito”? Esse é, como vimos, o debate.

Feitas as distinções entre regras e princípios e explicitado o conceito de justiça através de seus princípios, pelo menos a partir de alguns autores, é oportuno relacionar mais especificamente a atuação dos juízes, em seu poder de interpretação e decisão, com os padrões da justiça.

Perelman, como vimos, concentra o ponto de partida de sua discussão em torno da concepção formal de justiça, ou o que chama de regra de justiça: deve ser dado tratamento igual para situações semelhantes. Um juiz, portanto, é justo, do ponto de 
vista formal, se aplicar de forma correta a regra justa (cf. E.D. p. 51). Pode-se observar que a regra da justiça contempla explicitamente o princípio do precedente: 0 tratamento anterior de uma situação semelhante. Isso significa que o juiz só pode afastar-se do precedente na medida em que fornece "razões suficientes”. Não se pode, por qualquer motivo, fazer tabula rasa do nosso passado intelectual. A justificação do afastamento (do precedente), segundo o referido autor, se dará através do recurso à argumentação, que será “qualificada de racional quando se achar que é válida para um auditório universal, constituído pelo conjunto das mentes razoáveis” (E.D. p. 94). Portanto, embora o precedente seja a regra da justiça, ele não é absoluto, considerando: $1^{\circ}$ - que regras podem ser injustas ou duvidosas e $2^{\circ}$ - que a aplicação de certas regras pode produzir conseqüências injustas. Logo, ele não precisa e nem deve aplicá-las, mas terá que apresentar a justificação das escolhas feitas e da mudança proposta. Mesmo a escolha do ou dos princípios para sua justificação deve ser fundamentada em concordância com o auditório universal, critério último de justiça, embora também não absoluto.

O juiz pode e deve, portanto, levar em consideração as conseqüências da aplicação das regras, quando lhe parecerem injustas ou contrárias a sua consciência. Deve, no entanto, seguir o precedente enquanto não tiver motivos para mudar. E há duas razões que justificam a mudança: a experiência e a consciência (cf. E.D. p. 141). Se por razões políticas e morais as conseqüências da adoção do precedente lhe parecerem injustas, deve propor uma reinterpretação das leis. Perelman admite que nessa justificação, embora de acordo com o auditório universal, há sempre certa arbitrariedade (no sentido da necessidade de escolhas), o que é próprio do caráter normativo do Direito. É preciso insistir: a justificação de princípios e valores implica em escolhas. Admitem-se, portanto, "reviravoltas de jurisprudência”, “determinadas por uma reação quanto às conseqüências” (E.D. p. 141). Donde se conclui que os juízes aplicam leis injustas se quiserem. Escreve Perelman: "não disse que era preciso sempre seguir os precedentes, mas que se deve segui-los quando não se tem razões para se opor a eles. Há sempre razões, e são razões que importam, quando se derrubam os precedentes” (E.D. p. 141).

$\mathrm{Na}$ verdade, o que o hermeneuta faz quando justifica princípios e valores ou princípios através de valores, é um apelo à razão. E um apelo à razão é um apelo ao auditório universal, ou seja, é uma tentativa de convencer, mediante o discurso, os membros do auditório universal, constituído pelos "homens razoáveis e bem informados" (E.D. p. 385). Dizer que uma regra injusta é arbitrária porque não justificada racionalmente, significa que ela não é aceitável para o auditório universal. Rawls vai na mesma linha ao mostrar que "o judiciário apresenta a sua doutrina por meio de arrazoados e argumentações; sua concepção de constituição deve, se quiser perdurar, persuadir a maior parte dos cidadãos sobre a sua validez.” E continua: “O tribunal de última instância não é o judiciário, nem o executivo, nem o legislativo, mas sim o eleitorado como um todo” (T.J. p. 433). Dessa forma, “a constituição não é o que a Suprema Corte diz que ela é, e sim o que o povo, agindo constitucionalmente por meio dos outros poderes, permitirá à Corte dizer que ela é” (L.P. p. 288). Isso, numa linguagem hegeliana, significa dizer que a Suprema Corte é o intérprete do espírito de um povo e, por extensão, do "espírito do tempo". Ao tratar do Supremo Tribunal 
como exemplo de “razão pública”, Rawls mostra que a função dos juízes é procurar desenvolver as melhores interpretações da Constituição, sem poderem invocar sua moralidade ou a moralidade em geral, nem suas doutrinas religiosas ou filosóficas. Podem, tão somente, como vimos, apelar para os valores políticos que constituem a concepção pública e política de justiça, pois é em torno de tais valores que podem esperar o endosso dos cidadãos razoáveis e racionais. Hegel, por sua vez, faz toda uma fundamentação ética da Constituição a partir do "espírito do povo". Bobbio, em excelente artigo sobre a Constituição em Hegel, chama a atenção para "a insuficiência de toda consideração estritamente jurídica do Estado” (Estudos sobre Hegel, p. 104). Evidencia a concepção ético-política da Constituição do autor alemão, através do conceito de "espírito do povo" e comenta: “a vontade racional do Estado se expressa juridicamente através da lei (...). Enquanto a garantia da existência de uma lei é, em última instância, a força do Estado (...), a garantia da existência de uma Constituição reside unicamente no espírito do povo" (idem, p. 105). Este, no entanto, deve estar em sintonia com o "espírito do tempo" que, por sua vez, deve estar integrado com o “espírito do mundo”, que pode ser tido como uma espécie de "auditório universal”.

Apesar da semelhança do tipo de interpretação dos juízes atribuída por Rawls, Dworkin e Perelman, há uma diferença essencial, pelo menos entre os dois primeiros. Para Rawls, na interpretação da Constituição, os juízes “devem apelar para os valores políticos abrangidos pela concepção política e pública de justiça” ou uma variante desta, mas não podem invocar doutrinas morais abrangentes ou partes de uma moralidade. Esta é ampla demais. Dworkin, no entanto, aproxima as questões morais das questões jurídicas, principalmente na justificação de princípios. Para Perelman, se os juízes, seguindo o precedente, chegarem a conclusões inaceitáveis podem, por razões políticas, morais ou sociais, reconstruir "o conjunto da legislação" de modo a chegarem à resultados admissíveis e integráveis na ordem jurídica. Podem, portanto, apelar para as razões morais na interpretação das leis e justificação de princípios e valores.

Fica evidenciada, em Hegel e Dworkin, a íntima vinculação entre questões éticas e questões jurídicas. Isso mostra que os juízes, nas suas decisões, devem levar em conta os princípios éticos universalmente reconhecidos, ou pelo menos reconhecidos por determinadas comunidades éticas, isto é, o espírito de um povo, até porque o auditório universal é sempre uma "idéia situada histórica, social e psicologicamente" (E.D. p. 144). Nesse ponto Rawls diverge. Embora não desenvolva explicitamente uma teoria do poder discricionário, o que o distingue de Dworkin é o conteúdo dos princípios. Para Rawls os princípios de justiça têm apenas um conteúdo político e aplicam-se ao domínio do político. Recorre a valores, mas tão somente a valores políticos. ${ }^{21}$ Isso muda o tipo de justificação e argumentação a ser desenvolvida em prol dos princípios, sobretudo na fundamentação das regras. A partir de Rawls, poderíamos dizer que a restrição dos princípios de justiça ao domínio do político é fundamental para limitar o poder (discricionário) dos juízes. Estes podem recorrer a

${ }^{21}$ Os valores aos quais Rawls se refere são os valores da justiça, expressos pelos princípios da justiça: os valores da igual liberdade política e civil; igualdade eqüitativa de oportunidades; o respeito mútuo entre os cidadãos, etc. (cf. LP, p. 185 e JER, p. 270). Ver, também, O Direito dos Povos, p. 189. Aqui há uma referência aos valores políticos mencionados na Constituição dos EUA. 
valores para justificar princípios, mas somente aos valores políticos. Se já é difícil convencer o auditório universal através de valores políticos, a dificuldade aumenta quando se lhes dá um conteúdo moral ou religioso. Daí a dificuldade de construir uma concepção de justiça. Rawls, ao limitar os princípios e os valores ao âmbito do político, viabiliza o consenso em torno dos princípios e limita a âmbito de justificação e argumentação do sistema judiciário. O autor está, obviamente, mais preocupado com a construção de princípios justos, de acordo com os quais se tomam as decisões, tanto legislativas quanto judiciais. Sabemos quais são os princípios e como se chega a eles. Aqui há um avanço em relação à Dworkin e Perelman.

Outra alternativa do juiz, quando seguir o precedente trouxer conseqüências absurdas, é o recurso à eqüidade, que é um recurso do juiz contra a lei. Nesse ponto Perelman retoma Aristóteles. Somente se deve recorrer à eqüidade quando a lei parece "manca", diz o autor e escreve: "apela-se ao senso de eqüidade quando a lei, aplicada rigorosamente, em conformidade com a regra da justiça, ou quando o precedente, seguido à letra, conduzem a conseqüências iníquas” (E.D. p. 163). É o que pode acontecer quando se deve aplicar a lei a um fato particular, não pensado pelo legislador, ou quando circunstâncias externas (guerra, catástrofe) modificam as condições de um contrato a tal ponto de seu cumprimento trazer lesões absurdas.

Deve-se acrescentar que, acima de tudo, o juiz dispõe do "poder de interpretação", e ele o possui sempre, uma vez que, tanto as leis quanto os precedentes, não são aplicados mecanicamente. O raciocínio jurídico é um raciocínio dialético e não analítico, como o é da matemática. É isso que pode levar o juiz a considerar as conseqüências da aplicação de um raciocínio e retroceder às premissas reinterpretando-as para evitar resultados injustos. Ter o poder de interpretação é ter a possibilidade de “dizer o direito", até porque ele não pode recusar-se a fazê-lo a pretexto da obscuridade da lei. Nesse caso, quanto mais insuficiente e imprecisa uma lei maior será a necessidade e o poder de interpretação. Por todos esses aspectos, fica claro que o juiz não pode contentar-se em aplicar a "regra da justiça”. Ao servir-se de seu poder de interpretação e apreciação, visa conformar suas decisões ao seu "senso de eqüidade”. Decidir de acordo com a regra da justiça apenas nos diz que um ato é formalmente justo se houver tratamento igual para situações semelhantes. Isso, evidentemente, em vista da regularidade, nos dá mais segurança, mas não necessariamente justiça. A observância da regra da justiça não nos permite julgar as próprias regras. A eqüidade, no entanto, diz Perelman, "pode prevalecer sobre a segurança” (E.D. p. 116) e para evitar conseqüências desastrosas, pode o juiz mudar os efeitos da lei. Em nome da eqüidade, pode "rejeitar a justiça formal". Ele não tem o direito de legislar, e nesse sentido não tem poder discricionário, mas tem o poder de interpretação. É claro que, como dissemos, ele terá que justificar suas decisões que se afastam da jurisprudência.

Em síntese, o poder de interpretação, em nome da eqüidade, permite ao juiz, para evitar conseqüências iníquas, afastar-se do precedente e dar nova interpretação da lei. Permite-lhe modificar suas condições de aplicação, justificando-as, com boas razões, diante do auditório universal, que é uma espécie de senso comum ou opinião pública, e obtendo dele sua concordância. O juiz justo, ao administrar a justiça, não é mero espectador, mas tem a missão de “dizer o direito" ou como escreve Perelman: 
“não há direito senão quando há juízes para o dizer” (ED, p. 403). E isso vai muito além da aplicação do princípio do precedente, a regra da justiça.

É claro que sempre voltamos de novo ao "princípio da inércia”: não se deve mudar nada sem razão, ou positivamente falando, só se devem abandonar as regras existentes por boas razões. Apenas a mudança necessita de justificação (cf. E.D. p. 381 e 382) e essa deve ser feita de acordo com o "espírito do tempo", que também se constitui de princípios normativos. A ênfase do bem julgar não está na regra do precedente, mas na justificação da mudança (para evitar injustiças). Está na apresentação de soluções razoáveis, submetidas à aprovação do auditório universal, "constituído pelo conjunto dos homens normais e competentes” (E.D. p. 399). Soluções razoáveis são aquelas que podem ser justificadas pelas "melhores razões".

Fica evidenciado que o sistema do Direito é um sistema aberto, no sentido de ser perfectível, e não um sistema lógico-formal. A missão do juiz, por isso, torna-se mais difícil. Suas decisões devem ter a força de convicção suficiente. Ainda que deva aplicar a lei, deve dispor do raciocínio dialético (jurídico) para adaptar as regras ao resultado buscado; sua intervenção "possibilita introduzir no sistema jurídico considerações relativas à oportunidade, à justiça e ao interesse geral” (E.D. p. 426). O recurso ao "estado de necessidade", chamado por Hegel de "estado de emergência", é um exemplo típico que dá aos juízes a possibilidade de tomar decisões mais justas e satisfatórias. A propósito, o "direito de emergência” é um duro golpe ao formalismo moral, do tipo kantiano, do qual Kelsen é fiel herdeiro.

\section{REFERÊNCIAS BIBLIOGRÁFICAS}

RAWLS, J. Uma Teoria da Justiça. São Paulo: Martins Fontes, 1997. O Liberalismo Político. São Paulo: Ática, 2000.

Justiça como Eqüidade: uma reformulação. São Paulo: 2003.

O Direito dos Povos. São Paulo: Martins Fontes, 2004.

DWORKIN, R. Levando os Direitos a Sério. São Paulo: Martins Fontes, 2002.

El Domínio de la Vida. Barcelona: Ariel, 1998.

PERELMAN, C. Ética e Direito. São Paulo: Martins Fontes, 2002.

HOBBES, T. Leviatã. São Paulo: Abril Cultural, 1983. (Col. Os Pensadores).

ROUSSEAU, J. J. Do Contrato Social. São Paulo: Abril Cultural, 1980.

Discurso sobre a Desigualdade entre os Homens. São Paulo: Abril Cultural, 1980.

HABERMAS J. Consciência Moral e Agir Comunicativo. Rio de Janeiro: Tempo Brasileiro, 1989.

KANT, I. Fundamentação da Metafísica dos Costumes. Lisboa: Edições 70, 1980.

HEGEL, G. W. F. Grundlinien der Philosophie des Rechts. Frankfurt am Main: Suhrkamp, 1986.

GOMES, Alexandre / MERLE, J. C. A Moral e o Direito em Kant. Ensaios Analíticos. Belo Horizonte: Mandamentos, 2007.

SARLET, Ingo (org.). Dimensões da Dignidade. Porto Alegre: Livraria do Advogado, 2005.

WEBER, Thadeu. “O Direito de Propriedade e a Constituição Federal de 1988”. IN: Direito e Justiça. Porto Alegre: EDIPUCRS, v. 32, nº 2006, pp. 207-219.

Ética, Direitos Fundamentais e Obediência à Constituição. IN: Direitos Fundamentais, Informática, e Constituição. Ingo Sarlet (org.). Porto Alegre: Livraria do Advogado, 2007. 